\title{
PUBS. REFERENCE
}

STATE OF ALASKA

Bill Sheffield, Governor

Esther C. Wunnicke, Commissioner,

Dept. of Natural Resources

Ross G. Schaff, State Geologist
OIL-AND-GAS

RESOURCES

OF
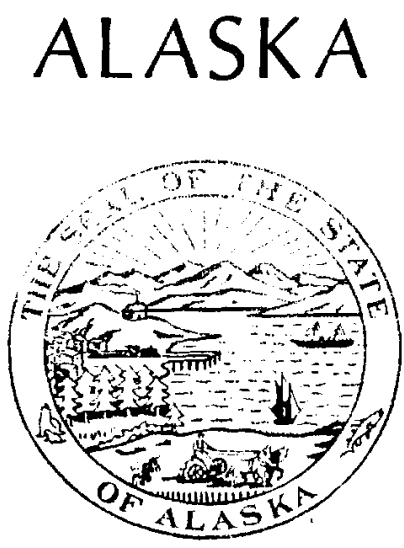

1985

INFORMATION CIRCULAR 31 


\section{CONSTITUTION OF THE \\ STATE OF ALASKA \\ Article VIII, Section 1}

It is the policy of the State to encourage the settlement of its land and the development of its resources by making them available for maximum use consistent with the public interest.

Information about Alaska's natural resources is available from the Office of the Commissioner, Department of Natural Resources, 400 Willoughby Center ( 5 th floor), Pouch M, Juneau, Alaska 99811 (phone 907-465-2400). 


\section{OIL-AND-GAS RESOURCES OF ALASKA}

\section{History of Oil-and-gas Exploration and Development}

Oil seeps in Alaska were first reported by Russian traders over $\$ 30$ years ago. The first exploratory wildcat well was drilled on the Iniskjn Peninsula on the west side of lower Cook Inlet in 1898 , and in 1902 , the first commercial hydrocarbon discovery was drilled at Katalla, Gulf of Alaska. The Katalla field produced oil until 1931, when the topping plant burned. This plant had supplied refined petroleum products to the Kennicott Copper Mine at McCarthy.

The first major oil field in Alaska was discovered in 1951 on the Kenai Peninsula, when the Richfjeld Oil Company initially drilled the Swanson River field. Other commercial oil-andgas discoveries in the area soon delineated the Kenai Peninsula as a major petroleum-producing province.

The Atlantic Richfield Company discovered the supergiant field, Prudhoe Bay, in 1968. At the time of discovery, this field had producible reserves of approximately 9.6 billion barrels of oil and 26 trillion cubic feet of gas. In 1977, after nearly 4 years of

Oil-and-gas-producing platform in Cook Inlet, Alasho. Photograph courtesy of the U.S. Department of Interior Winerals Management Service, 1980.

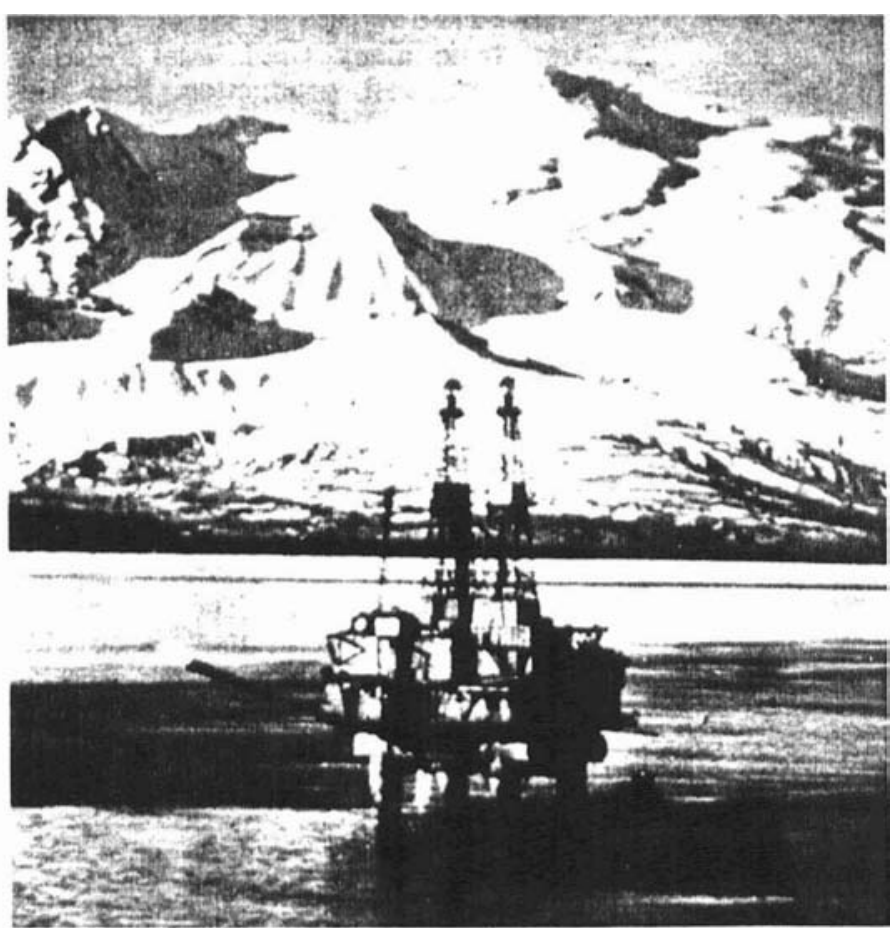




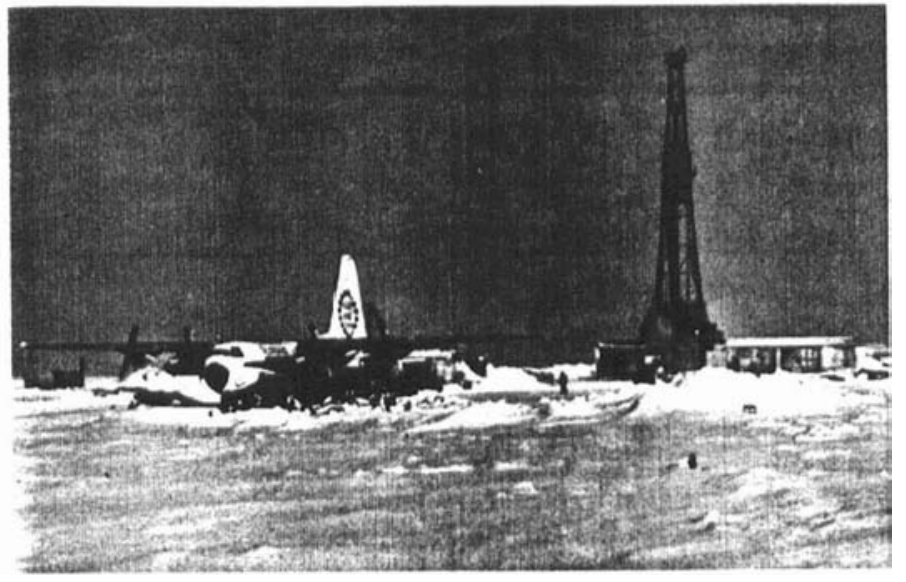

The Prudhoe Bay discovery well was drilled by the Atlantic Richfield Com. pany in 1967-68. C-130 Hercules planes were used to fly in the drill rig, camp, and oll drilling supplies. Photograph by C.G. Mull, March 1968.

construction-and at a cost of $\$ 7.7$ billion-the Trans-Alaska Pipeline System was completed. Since then, oil has moved through the pipeline from Prudhoe Bay to Valdez, where it is loaded onto tankers for shipment to refineries along the west coast.

\section{Current Prospects}

Approximately 85 percent of the State of Alaska's current revenue is derived from royalties and taxes paid on state-owned oil-and-gas leases. Production from many Cook Inlet fields is declining, and production from the Prudboe Bay field is expected to sub. stantially decline in the 1990 s.

Indications from current North Slope oil-and-gas exploration are encouraging. Recently discovered ac cumulations in the following areas are estimated to total 2.5 billion barrels of recoverable oil.

口 Kuparuk field: Approximately 1.2 billion barrels of recoverable oil; currently producing over 190,000 barrels per day.

口 Duck Island - Sag Delta area: 1.1 billion barrels of in-place oil with up to 350 million barrels recover. able, not including an unknown quantity of free and associated gas. Production is from Endicott Group rocks that are not productive in the Kuparuk and Prudhoe Bay fields.

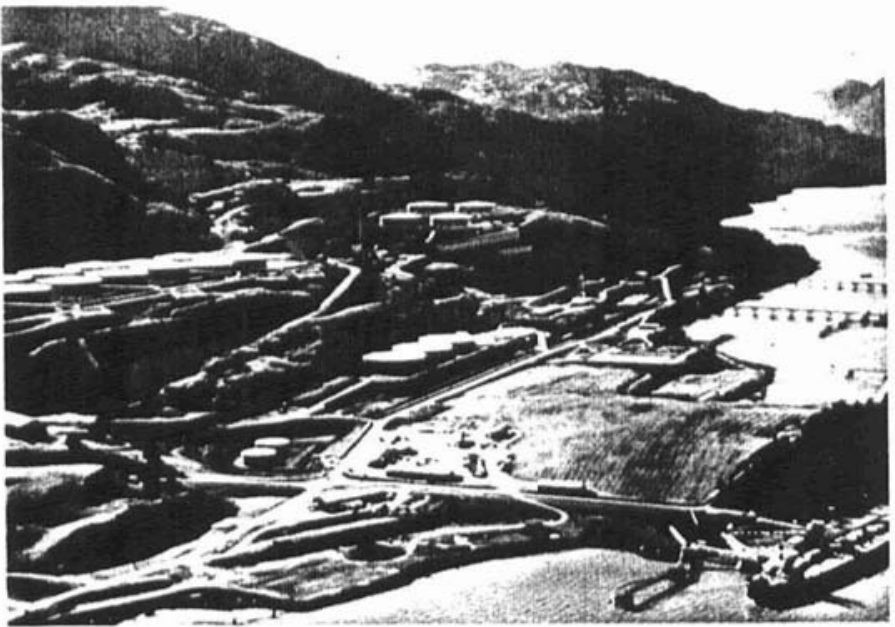

Aerial view of the Alyeska Pipeline Terminal, Valdez, Alaska. Photograph courtesy of Alyeska Pipeline Service Company, 1984.

口 Point Thompson area: Estimates of 350 million barrels of recoverable condensate (very high gravity, highquadity oil) and 6 trillion cubic feet of recoverable gas.

Q Lisbume Pool: 3 billion barrels of in-place oil that underlie the producing Sadlerochit reservoir (Prudhoe Bay field); possibly 500 million barrels recoverable.

a Milne Point area: 60 million barrels of recoverable oil.

DGwydy Bay area: 30 million barrels of recoverable oil.

Other discoveries are in the early stages of delineation:

- West Sak - Ugnu area: These shallow sands contain large reserves of heavy oil. Fifteen to 25 billion barrels of oil may be in place in the West Sak sands, with as much as 3 to 5 billion barrels ultimately recoverable. Although preliminary hot-water-injection projects are being conducted, commercial production is uncertain. Commercial cevelopment of heavy oil in the shallow Ugnu sands ( 6 to 11 billion barrels in place) is currently beyond the technological capability of industry.

a Seal Island: The discovery well produced up to 5,000 barrels of $40^{\circ}$ gravity oil and 10 million cubic feet of gas per day. Delineation wells are currently being drilled. 
Construction of North Star Island was completed in 1985. Concrete blocks replace the traditionally used gravelfilled bags that protect other gravel islands from erosion by pach ice and wind-driven summer waves. Other man-made gravel islands lave been effectively used for oil-and gas drilling operations. Photograph courtesy of AlC-Martin, 1985.

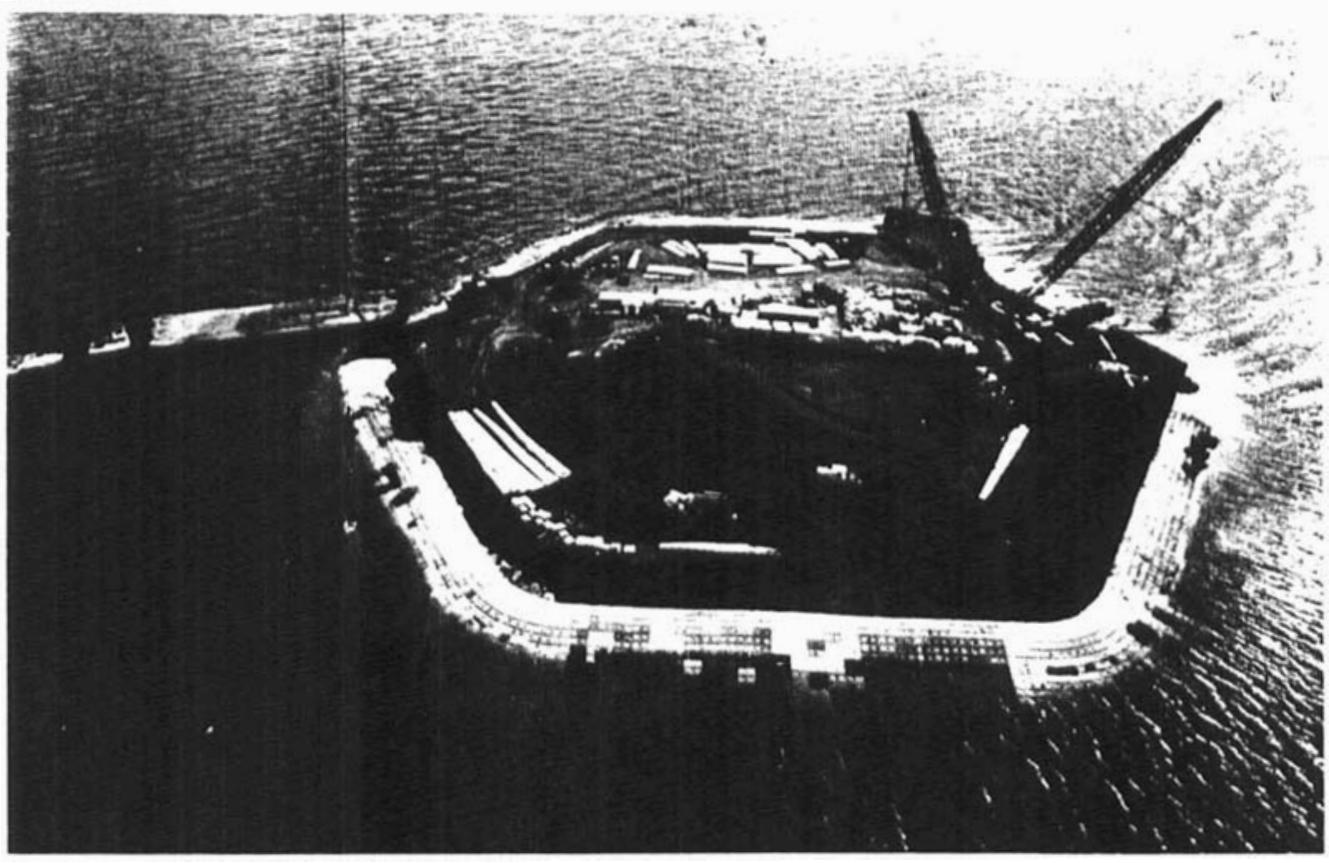

口Colville Deita: In 1985 Texaco announced a discovery well that produced from 414 to 1,076 barrets of oil per day. No estimate of in-place reserves has been made.

According to the National Petroleum Council (1981), estimates for undiscovered, conditional, in-place oil resources in Alaska range from 2.5 to 14.6 billion barrels onshore and 4.6 to 24.2 bijion barrels offshore (95-percent and 5-percent probability levels, respectively).

Between September 1984 and August 1985, exploratory drilting pro. ceeded at a moderate to fast pace. Of nine new welis drilled on state leases, Texaco announced one discovery at Colville Delta No. 1. Nineteen wildcat wells were drilled on federal leases in the St. George Basin, Norton Sound, Navarin Basin, lower Cook Inlet . Shelikof Strait, and Beaufort Sea areas, but none encountered commercial-grade hydrocarbon deposits. Additionally, one dry hole was drilled onshore on a federal lease in the National Petroleum Reserve Alaska.

Six federal outer continental shelf wells are operating in the state. Addi. tional permitted locations will be drilled during the tall of 1985 or during the 1985-86 winter drilling season.

Development activity is extensive in both the Prudhoe Bay and Kuparuk fields. Delineation and development drilling are especially active on the Seal Island and Milne Point accumulations. During the past year, the private sector proceeded with development of the Endicott reservoir at Duck Island and successfully used the first Concrete Island Drilling System (CIDS).

\section{Resource Estimates}

The map of Alaska (p. 9) identifies the state's hydrocarbon resources based on estimates by the U.S. Geological Survey and National Petroleum Council. These estimates were made in 1981 and were subsequently modified from Ehm (1983) for this document. Resource estimates released in July 1984 by the U.S. Department of Interior Minerals Management Service (Cooke, 1985) are also shown on the map. The Alaska Department of Natural Resources Division of Geological and Geophysical Sur. veys recently published Special Report 32 (Ehm, 1983), which shows major oil-and-gas basins in Alaska.

\section{Oil-and-gas Leasing Program}

The Alaska Department of Natural Resources is responsible for managing Alaska's oil-and-gas resources. Annually a 5-year schedule for the leasing of state land Eor oil-and-gas exploration is submitted to the Legislature. The major purpose of this schedule is to facilitate the orderly assessment and development of Alaska's petroleum resources. All Alaskans, including local citizens and governments, environmental groups, the oil-and.gas industry, and the business sector benefit from a fixed and predict- 


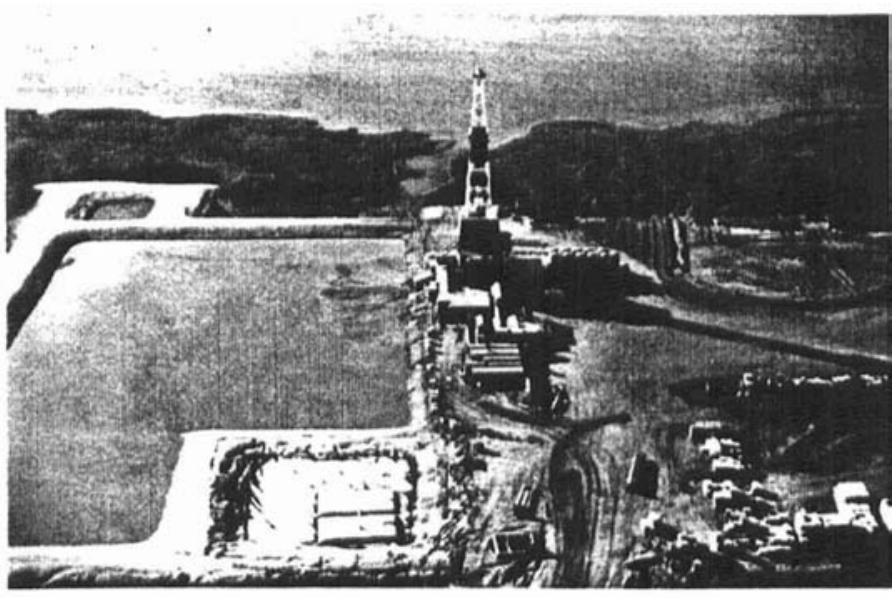

Gravel pad, containment pit, and drill rig on the North Slope near Prudhoe Bay. Photograph by S.E. Rawlinson, 1978 .

able leasing program because an established leasing schedule permits the public to comment on areas that may be leased, allows business and labor to plan employment or business opportunities, permits the petroleum industry to allocate a portion of its resources to petroleum exploration and development, and gives local, state, and federal governments adequate time for presale evaluation, assessment, and mitigation of impacts. The 5-year lease-sale schedule may be obtained from the Alaska Department of Natural Resources Division of Oil and Gas (1985).

Exploration Activity in the

Arctic National Wildlife Refuge

Oil-industry interest is currently focused on the Arctic National Wildlife Refuge (ANWR) in anticipation of a Congressional decision about leasing within the refuge. The Congressional decision, which is to be made in 1986 or 1987, will partly be based on estimates by federal and state geologists of probable oil resources within the refuge.

The Department of Natural Resources Division of Geological and Geophysjeal Surveys is conducting a petroleum. resource analysis of ANWR. During the summer of 1985 , in cooperation with the Bureau of Land Management, Survey geologists conducted extensive field studies in the refuge. The informa. tion collected during this field program will be used to interpret confidential seismic and well data, including 1984 and 1985 ANWR seismic and offshore data within the 6 -mile limit.

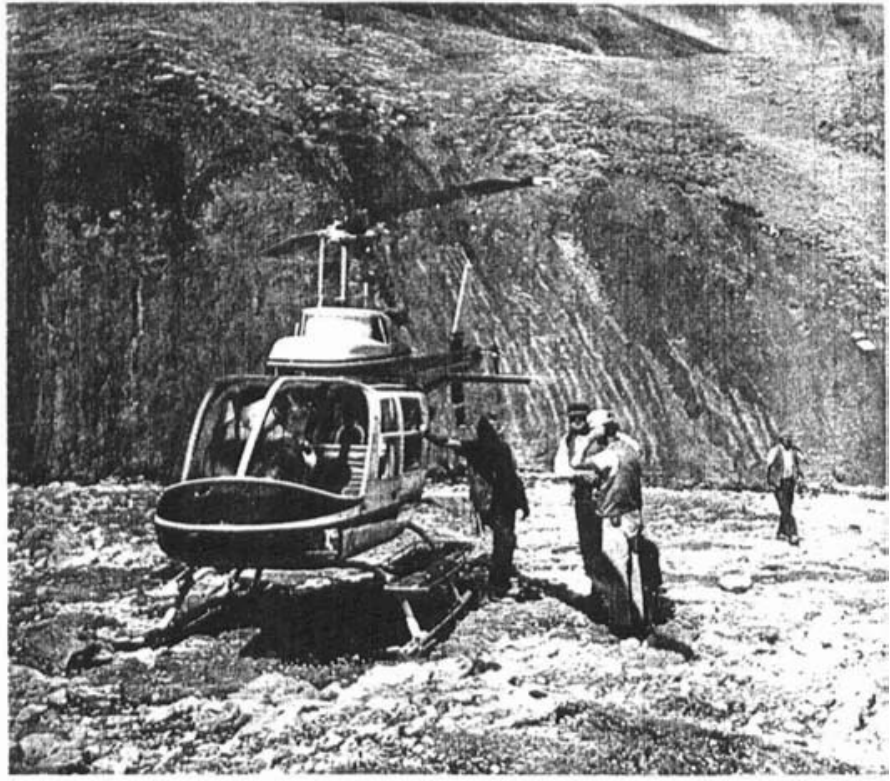

Geologists from the Alaska Division of Geological and Geophysical Surveys collect field data in the Arctic National Wildlife Refuge, North Slope, Alasha. Photograph courtesy of C.G. Mull, 1985 .

Alaska Department of Natural Resources Division of $O i]$ and Gas, 1985, Five-year oil and gas leasing program January 1985: p. 1-2.

American Petroleum Institute, 1985, Basic petroleum data book, January 1985, Petroleum industry statistics: v. 5 , no. 1

Cooke, L.W. 1985, Estimates of undiscovered, economically recoverabje oil and gas resources for the outer continental shelf as of July 1984 : U.S. Department of the Interior Minerals Management Service Outer Continental Shelf Report MMS 85- $1012,45 \mathrm{p}$.

Ehm, Arlen, 1983, Oil and gas basins map of Alaska: Alaska Division of Geological and Geophysical Surveys Special Report 32, scale 1:2,500,000, 1 sheet.

National Petroleum Council, 1981, L.S. Arctic oil and gas: Washington. D.C., $130 \mathrm{p}$.

U.S. Geological Survey, 1981, Estimates of undiscovered recoverable con. ventional resources of oil and gas in the United States: U.S. Geological Survey Circular 860, 87 p. 
U.S. DEPARTMENT OF INTERIOR
U.S. OEOLOGICAL SURVEYRESOURCE
ASSESSMENT AREAS

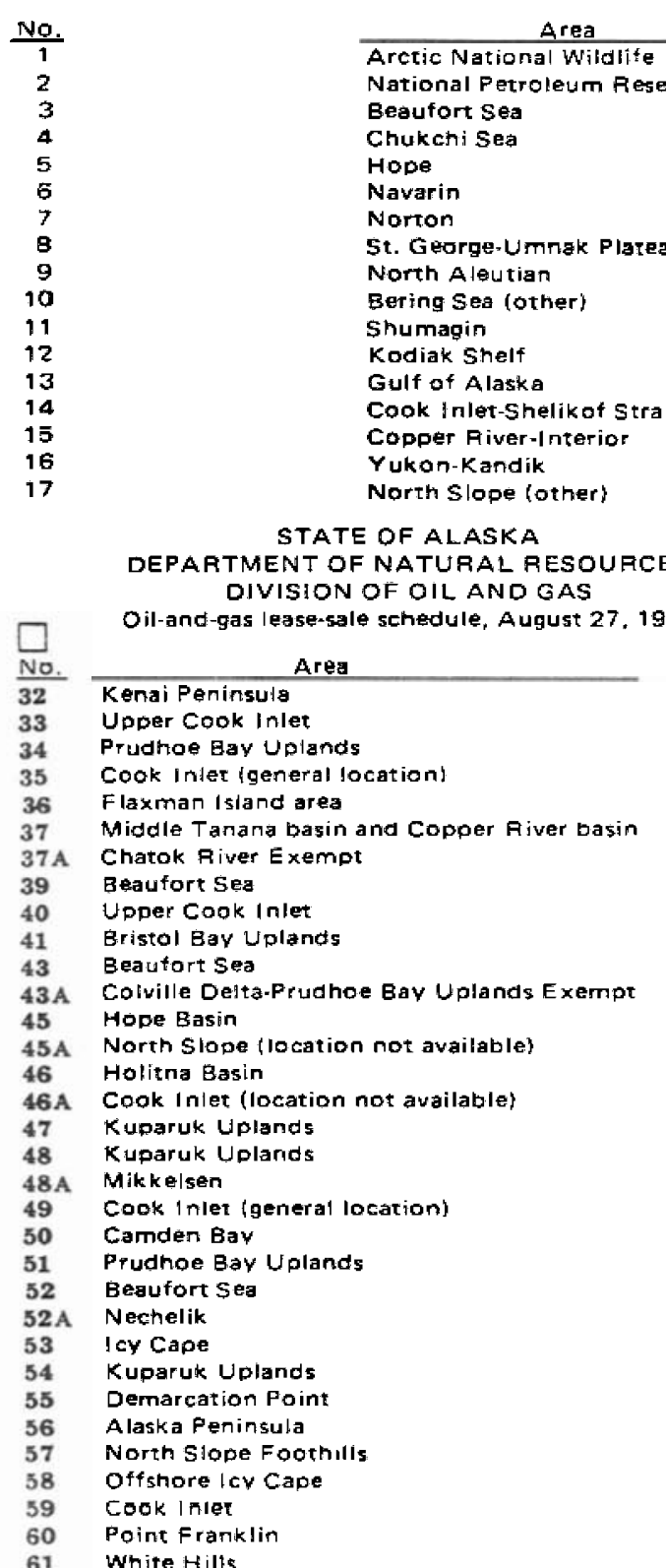

Area
$\frac{\text { Arcric National Wirdlife Refuge }}{\text { National Petroleutum Reserve-Alaska }}$

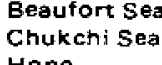

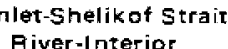

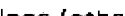

U.S. DEPARTMENT OF INTERIOR
Oil-and-gas lease-sale schedule issued 1985

$\square$ BUREAU OF LAND MANAGEMENT

$$
\begin{aligned}
& \text { leditarod.George } \\
& \text { Goodnews Bay } \\
& \text { Kvichak }
\end{aligned}
$$

Goodnews Bay
Kvichak
National Petroleum Res

Anvik-Bonsila
Sceese-white Mourntain
Central Yukon

Minerals MANAGEMENT SERVICE
(general location, April 1985)

83 Navarin Basin

$\begin{array}{ll}85 & \text { Sarrow Arch } \\ 86 & \text { Shumagin } \\ 87 & \text { Diair Field } \\ 89 & \text { St. George B }\end{array}$

$\begin{array}{lll}89 & \text { St. George Basin } \\ 92 & \text { N. Aleutian Basi } \\ \text { N } & \end{array}$

\begin{tabular}{ll}
92 & N. Aleutian Bas \\
97 & Diapir Field \\
\hline & Vorton
\end{tabular}

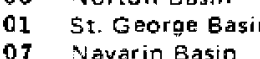

Earrow Arch/Chukchi
Barrow Archichuken

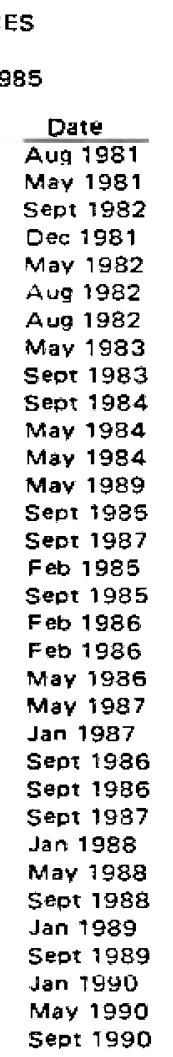

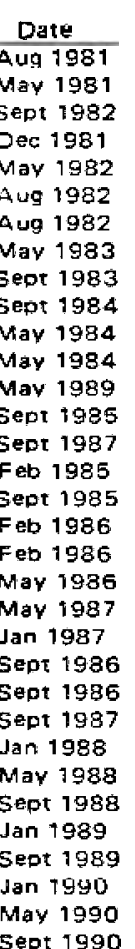

\section{Sept 1986
On nold \\ (n)
Sept 1986
sept 1987 Sept 1986
Sept 1987
Sept 1983}

\section{Apr 1984}

Nor
No 2 ate
Dec 1987
Aug 1984
Then 1986

Aug
No date
Jan 1986
Dec 1986
Jul

Mar 1986
July 1988
Sar

Set 1986
Mav 1986
mav 1990

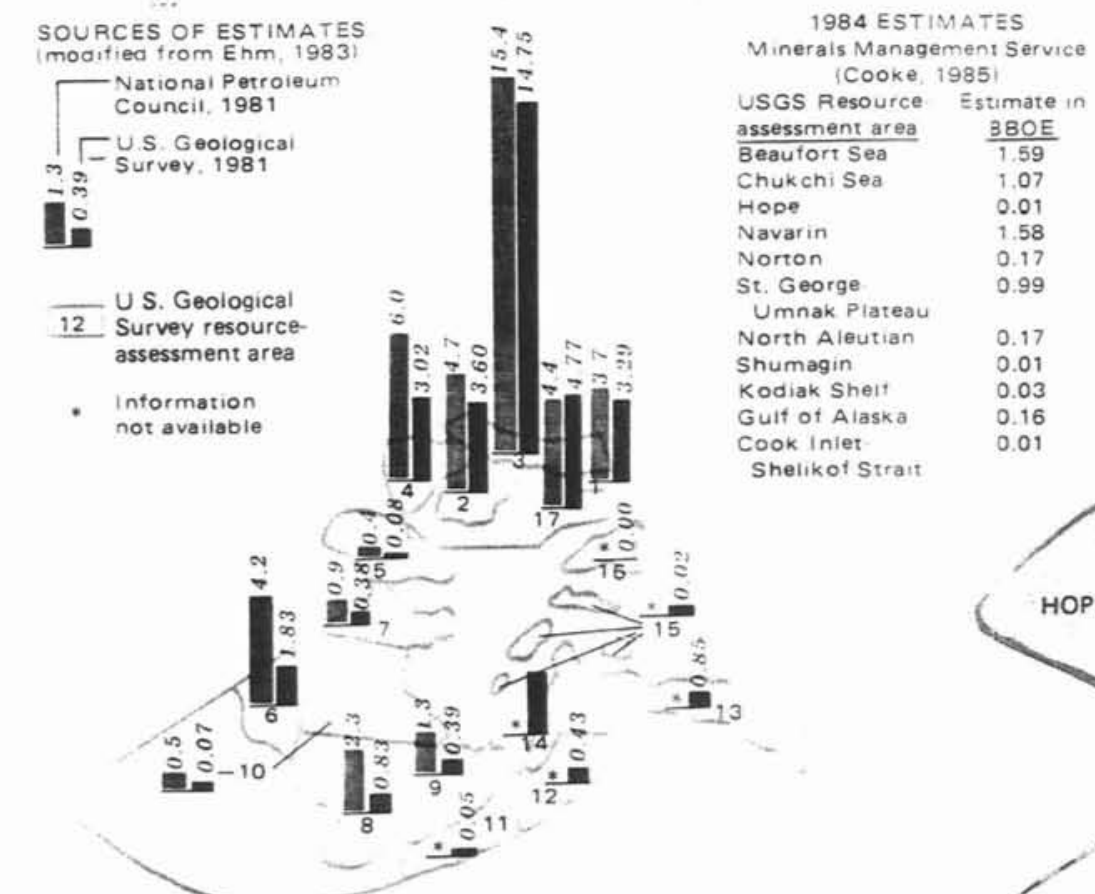

OIL-AND-GAS

RESOURCES OF ALASKA

Estimates of undiscovered, potentially recoverable hydrocarbons frisked mean vailues

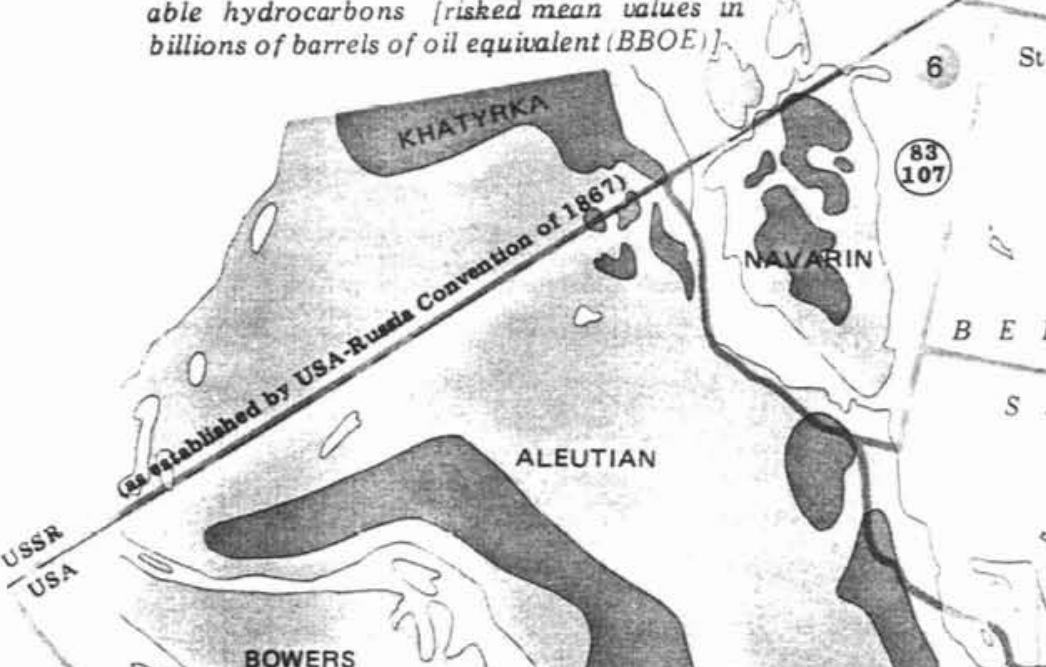

7) Nome Lov Mine Point, GWvary, Bav, Seari isianc
Lisourne Pooi, Duck isiano Sag Delce

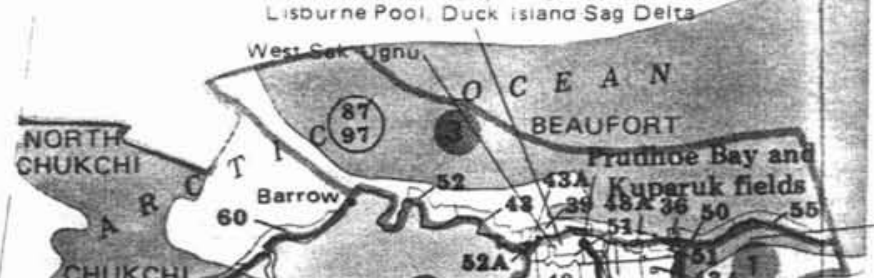

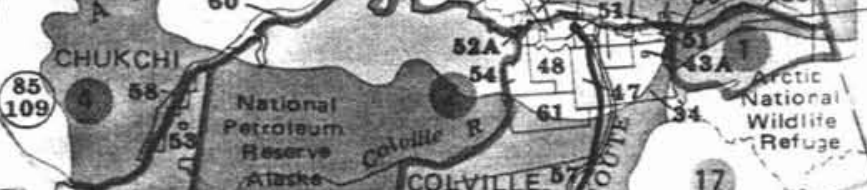

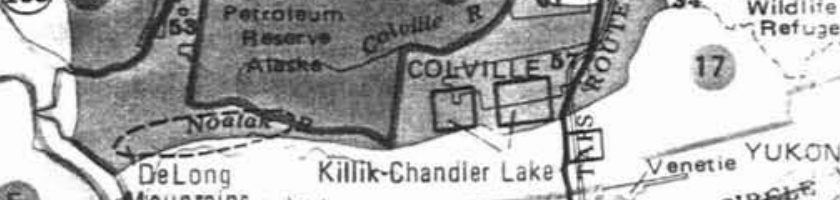

5 Thelong Killik-Ehander Lake

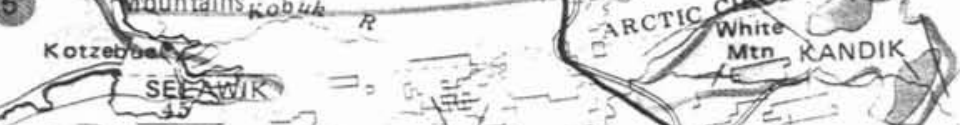

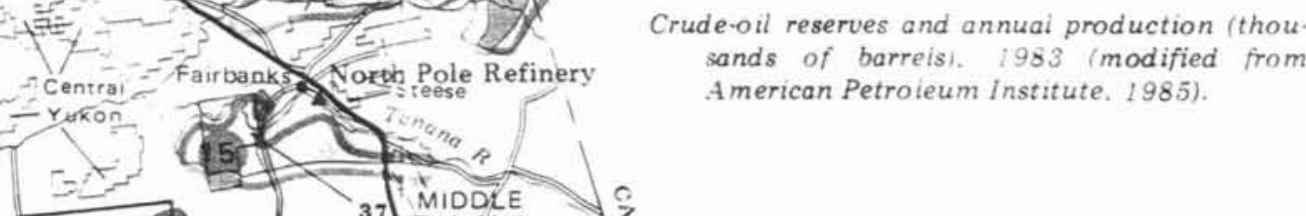

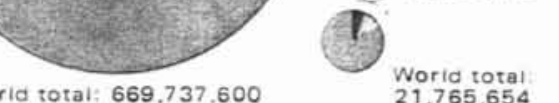

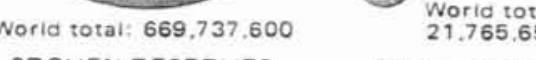

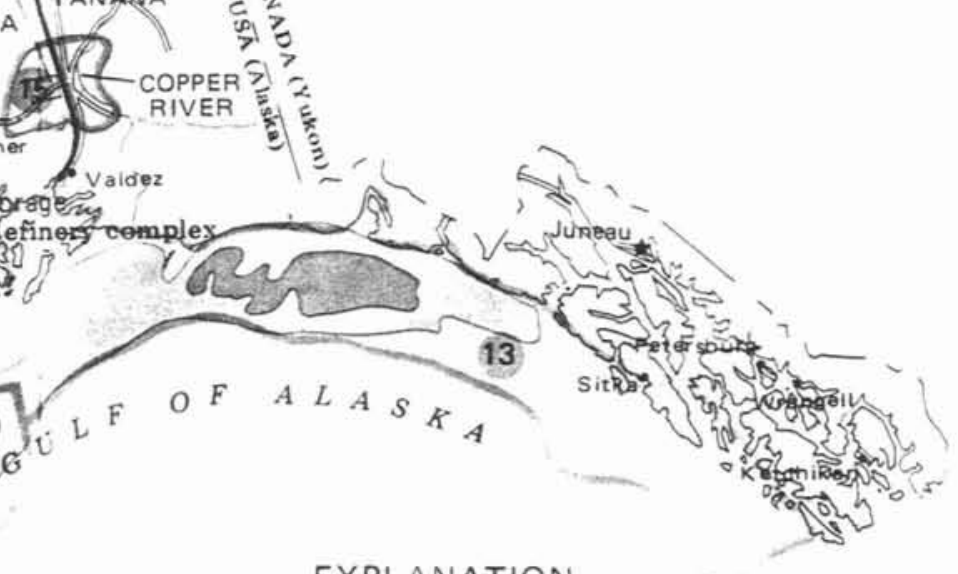

892

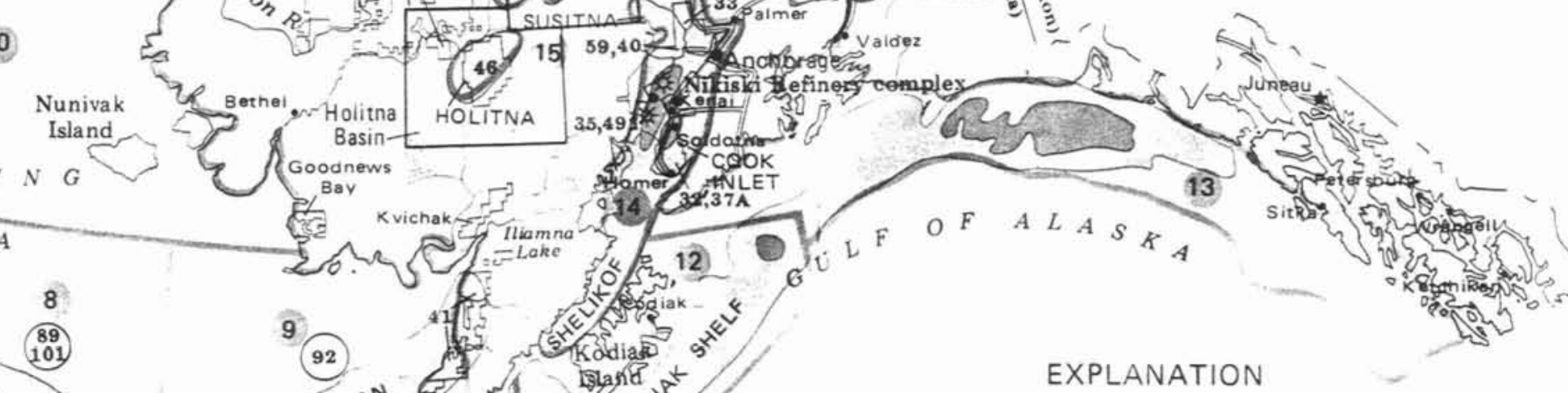

EXPLANATION

OL.AND.GAS BASINS - Thickness of sediment
(modified from Ehm, 1983)

1.]. More than 3.1 miles

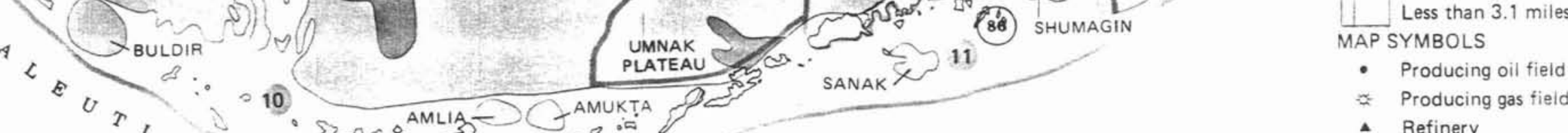

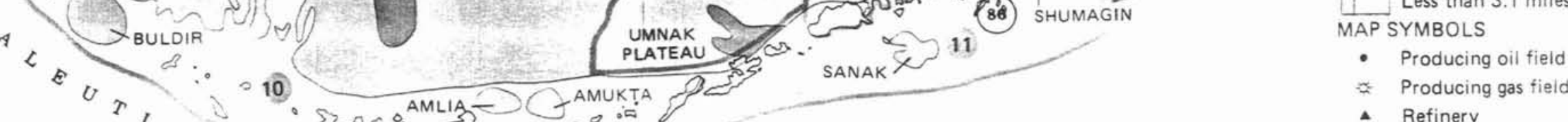

(3) Refinery

POPULATION CENTERS- Number of inhabitants. 1980

U.S. Geological Survey resource-assessment area (see inset map

Anchorage $\bullet 174,431$ OIL-AND-GAS LEASE-SALE AREAS (see schedules)

State of Alaska

U. Department of Natural Resources

U.S. Department of Interior

(86) Minerats Management Service (general location)

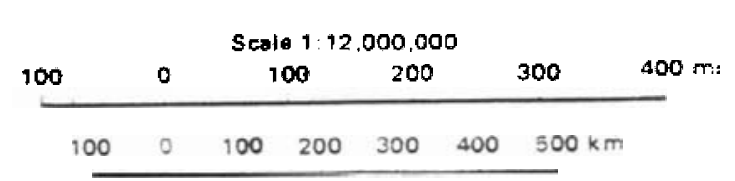

SELECTED TRANSPORTATION-UTILITY

DJGS OIL-AND-GAS INVENTORY PROJECTS

Current
Proposed 